\title{
DETERMINATION OF OPTIMAL CONTOURS OF OPEN PIT MINE DURING OIL SHALE EXPLOITATION, BY MINEX 5.2.3. PROGRAM
}

\author{
Miroslav Ignjatović ${ }^{1}$, Radmilo Rajković ${ }^{1}$, Snežana Ignjatović ${ }^{2}$, Lidija Đurđevac Ignjatović ${ }^{1}$, Lazar \\ Kričak $^{2}$, Radoje Pantović ${ }^{3}$ \\ ${ }^{1}$ Minig and metallurgy Institute Bor, Zeleni bulevar 33, 19210 Bor, Serbia \\ ${ }^{2}$ University of Belgrade, Faculty of mining and Geology, Đušina 7, 11000 Belgrade, Serbia \\ ${ }^{3}$ University of Belgrade, Technical Faculty in Bor, Vojske Jugoslavije 12, 19210 Bor, Serbia
}

\begin{abstract}
By examination and determination of optimal solution of technological processes of exploitation and oil shale processing from Aleksinac site and with adopted technical solution and exploitation of oil shale, derived a technical solution that optimize contour of the newly defined open pit mine.
\end{abstract}

In the world, this problem is solved by using a computer program that has become the established standard for quick and efficient solution for this problem. One of the computer's program, which can be used for determination of the optimal contours of open pit mines is Minex 5.2.3. program, produced in Australia in the Surpac Minex Group Pty Ltd Company, which is applied at the Mining and Metallurgy Institute Bor (no. of licenses are SSI - 24765 and SSI - 24766).

In this study, authors performed 11 optimization of deposit geo - models in Minex 5.2.3. based on the tests results, performed in a laboratory for soil mechanics of Mining and Metallurgy Institute, Bor, on samples from the site of Aleksinac deposits.

Keywords: Oil shale, sample testing, the Minex 5.2.3. program, the optimal open pit

\section{Introduction}

Determining the optimal contour of open pit mine is a necessary step in open pit mine exploitation. The main characteristic of this design phase is complexity and large number of possible solutions that meet technical technological conditions, but with differences, according to economic effect. Therefore, it is necessary to undergo various solutions to techno - economic analysis of individual variants and adopt a solution that will be optimal for the given conditions $[1,6,9]$.
This task can be solved by different methods, using classical techno - economic analysis or using modern techniques of mathematical programming. Techno Economic Analysis is performed using qualitative and quantitative predictions of all factors and conditions that can provide desired result. Qualitative assessment includes the following indicators: mining geological and hydro - geological conditions [1], organizational and economic factors [3, 7, 8]. Quantitative assessments include: funds use for a certain period of time, dynamics of investments, costs tones of products, effects, use of legislative materials and so on.

Methods of linear and dynamic programming are applied for solving problems with a large number of variants and possible solutions. To solve this task, there are several computer programs for data processing and model setup. Application of mathematical models can be established if there is a certain analogies and similarities between the mathematical formula and the actual work processes to be modeled.

\section{Description of MINEX 5.2.3 program}

The development of computer technology, and due to information revolution in the mid eighties of the twentieth century, appeared the first software packages specialized in areas of geology and mining. Today, these 
programs have evolved into extremely powerful and useful tool aimed at reducing time needed to produce geo-model of studied deposits and open pit mines, saving money and creating detailed 3D model of ore bodies and mines. One of these programs is Minex 5.2.3 which is a specialized program for 3D modeling, exclusively for layered deposits, especially coal deposits.

With this software it is possible to develop a geological model of layered deposits, to model faults, determine the optimal contour of open pit mines, construct a detailed appearance of open pit and tailing dumps, determine dynamics of excavation and disposal of tailings.

Starting point for work in this program is: situational map in digital format (topography for new mines or initial state of works on the open pits, usually in AutoCAD format) and data from exploratory drill holes about their spatial position, lithology and quality parameters in Excel format [1, 2, 3, 4, 6, 11]. Geomodel of the deposit is created based on data from the drill holes. Each layer in geo - model has its own grid (area represented by a network of certain dimension) of roof, floor and thickness of the deposit, as well as grid of quality for each observed component. Geo - model is produced by following tools:

$>$ Borehole $D B$ - Forming a base of boreholes for geological modeling

$>$ Statistical analysis - Analysis of the regularities of components distribution in the deposit

$>$ Seam model - Layers modeling and calculation of geological reserves

When the geo - model is created and initial state of terrain is put in, optimization is performing, i.e. determination of the optimal contour of open pit mine according to technical - economic parameters of exploitation. The resulting optimal contour is a guideline for detailed construction of open pit mine. This phase of design is done by Pit Optimizer tool.

In Minex 5.2.3 program, it is possible to construct a detailed layout of the final look of open pit mine and waste rock dumps with transport routes and top and bottom edges of each floor, as well as creating excavation dynamic by Pit design tool.

Also, with this program, it is possible to make full mining - geological graphic documentation.

\section{Geo - model of deposit}

Geo - model of oil shale deposit is made based on earlier data [1] and samples from the site, tested in the Mining and Metallurgy Institute Bor [6]. Following parameters have been systemized:

$>$ Spatial position - X, Y and Z coordinates of a borehole's mouth, the length of borehole pillar, azimuth and strike direction; deviation of borehole pillar;

$>$ Lithology per borehole pillar:

$>$ Content of important parameters (quality) per borehole pillar - oil content (ulj in the model) water content $\left(\mathrm{H}_{2} \mathrm{O}\right.$ in the model $)$; content of coke ( $p k$ in the model); gas component with losses ( $g g$ in the model).

On location of Aleksinac oil shale deposits are defined two basic layers, S1 and S2 (roof and floor oil shale layers, between which are layers of coal and overburden), but the S1 layer is divided into two parts, S1a and S1b, because, inside layer S1 are overburden inter-layers of significant thickness. The amount of overburden above the layers, the amount of oil shale in layers and quality parameters are shown in Table 1. 3D model of oil shale layers in Minex 5.2.3 program is shown in Figure 1. 
Table 1. Quantities and quality of Aleksinac oil shale deposit

\begin{tabular}{|c|c|c|c|c|c|c|c|c|c|}
\hline \multicolumn{10}{|c|}{ UPPER SURFACE: Topo.grd; LOWER SURFACE: S2SF.grid } \\
\hline \multirow{3}{*}{ Seam } & \multicolumn{2}{|c|}{ Waste } & \multicolumn{2}{|c|}{$\begin{array}{c}\text { Oil shale } \\
\end{array}$} & \multirow{2}{*}{$\begin{array}{l}\text { Strip } \\
\text { ratio }\end{array}$} & \multicolumn{4}{|c|}{ Assay } \\
\hline & Volume & Tonnage & Tonnage & Tonnage & & ulj & $g g$ & $\mathrm{pk}$ & $\mathrm{H} 2 \mathrm{O}$ \\
\hline & $\mathrm{m}^{3}$ & $\mathrm{t}$ & $\mathrm{m}^{3}$ & $\mathrm{t}$ & $\mathrm{m}^{3} / \mathrm{t}$ & $\%$ & $\%$ & $\%$ & $\%$ \\
\hline S1a & 458714392 & 688071588 & 91726433 & 190607527 & 2,41 & 12,31 & 5,17 & 76,65 & 6,03 \\
\hline S1b & 12412541 & 18618812 & 70142786 & 145756710 & 0,09 & 7,32 & 3,38 & 82,54 & 6,76 \\
\hline $\mathrm{S} 2$ & 73220337 & 109830506 & 53765704 & 111725133 & 0,66 & 11,59 & 5,88 & 76,66 & 5,58 \\
\hline TOTAL & 544347270 & 816520905 & 215634923 & 448089370 & 1,21 & 10,51 & 4,76 & 78,57 & 6,15 \\
\hline
\end{tabular}

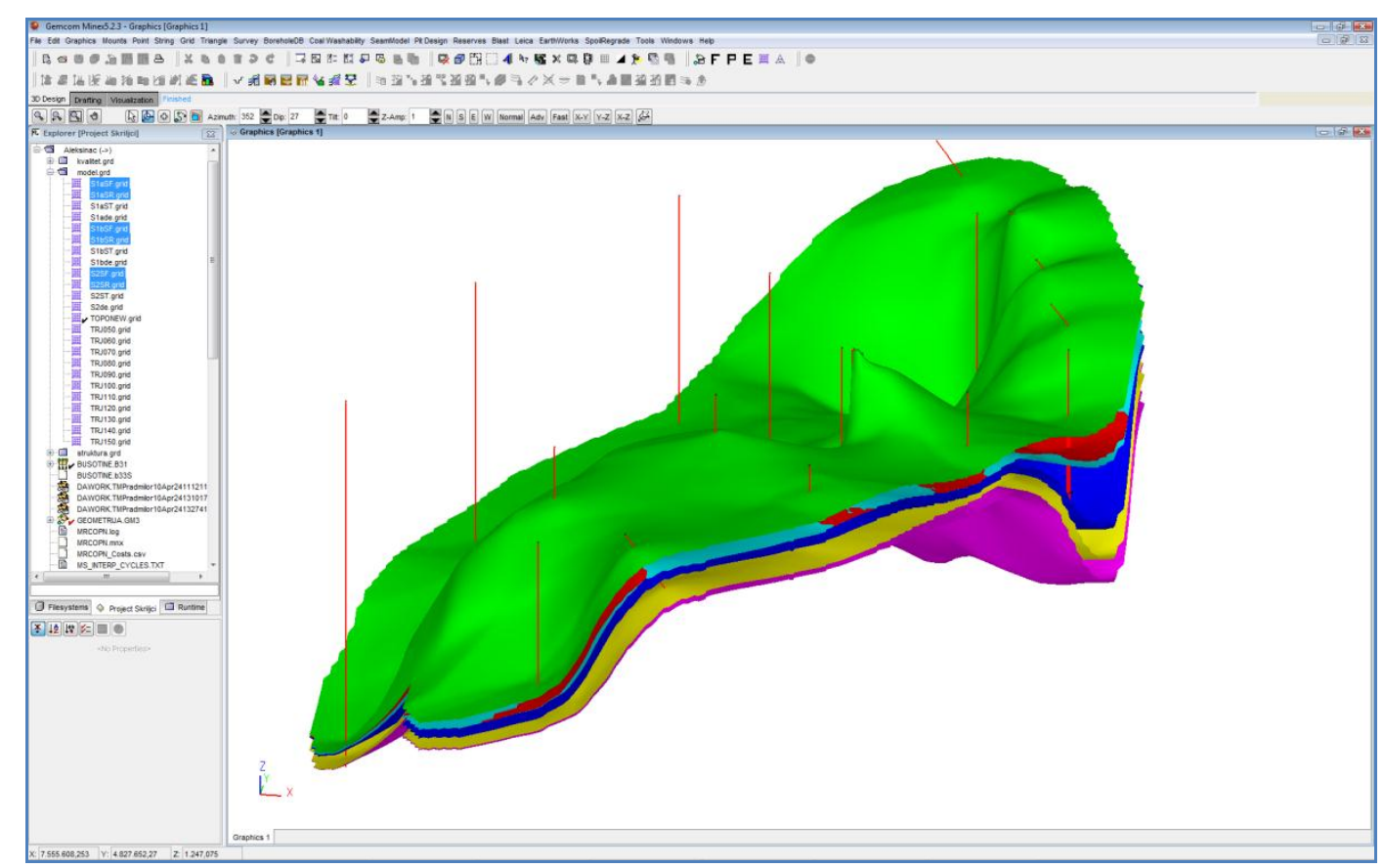

Figure 1. 3D model of oil shale layers in Minex 5.2.3 program 


\section{Selection of optimization input parameters}

Optimization of open pit mine in Minex 5.2.3, i.e. in his tool Pit Design, is done with Pit Optimizer option, which is based on Lerches and Grossman algorithm. Lerches and Grossman algorithm is a procedure for determining optimal mining as one with the highest value for the corresponding set of costs and recovery factors.

Input parameters for the Pit Optimizer are:

\section{Economic parameters:}

1.1. Selling price of oil

1.2. Costs of tailings excavation

1.3. Costs of oil shale excavation

1.4. Costs increasing caused by increasing depth of open pit mine

1.5. Costs of oil shale processing

1.6. Initial and final discount factor and discount factor step

\section{Technical parameters:}

2.1. Initial state of the terrain

2.2. Geo-model of the deposit

2.3. Bulk density of oil shale

2.4. Final pit slope angle

2.5. Minimum distance between floors in progress

2.6. Utilization of the exploitation

2.7. Utilization of processing oil

shale

Selling price of oil has been adopted by current market conditions to 85 $\$$ for barrel. Reduced to medium oil content in oil shale for the whole deposit, a value of $1 \%$ of oil is $\$ 2,57$.

Costs of tailings and oil shale excavation for optimization $[1,6,9,12]$ were adopted based on experience from open pit mines with similar conditions and they are $\$ 5.00 / \mathrm{m} 3$ of excavated overburden and 2,50 $\$ / \mathrm{t}$ of excavated oil shale. Costs increasing, with increasing depth of the open pit, was adopted, based on experience with open pit mines with similar conditions, and it is $0,01 \$ / \mathrm{m}$

Costs of oil shale processing $[9,12]$ include preparation of oil shale (shredding and separation from sterile and carbon components) and pyrolysis process. These costs, according to previous researches, are $\$ 12,00 / \mathrm{t}$

Discount factor is varied in the range of 0,5 to 1,5 of the selling price of oil, with step of 0,1 .

Oil shale bulk density is previously defined $[1,6]$. The mean value of dry density of oil shale, according to this document, is $2,078 \mathrm{t} / \mathrm{m}^{3}$.

Final angle of the open pit slope [5, $10,12]$, depending on its depth, is defined in [12] as the mean value of the final angle of the open pit, that will be used for optimization. Adopted value for an angle is $30^{\circ}$.

Minimum distance between floors, during progress of mining activities, is determined depending on the equipment used in the exploitation. Adopted distance is $20 \mathrm{~m}$.

Utilization on the open pit mine [9, $10,12]$ was adopted based on experience with open pit mines with similar conditions, and it is $90 \%$.

Utilization of the fragmentation and separation $[9,10,11,12]$ of sterile and carbon components is estimated at $75 \%$. Utilization of the pyrolysis is estimated at $85 \%$ on oil yield.

These data were put into the Pit Optimizer, which is shown in Figure 2. 


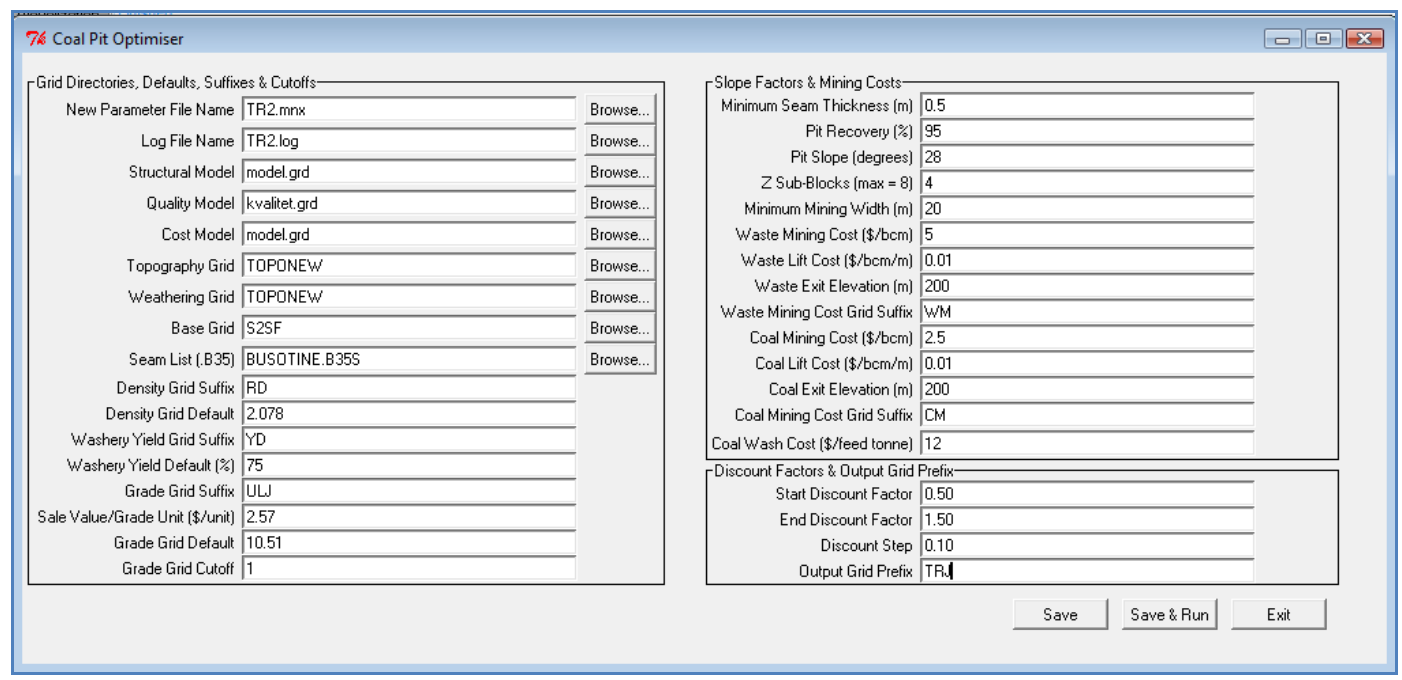

Figure 2. Input parameters for Pit Optimizer in Minex 5.2.3 program

\section{Results of optimization}

Eleven cases of optimal contour of open pit mine were analyzed by optimization, with varying of oil selling price discount factor $\pm 50 \%$ of market value, in steps of $10 \%$. Optimization results are shown in Tables 2 to 12 . Values of the open pit mines obtained by optimization are given in Table 13.

Table 2. Quantities and quality for open pit mine 1 with discount factor of 0,5

\begin{tabular}{|c|c|c|c|c|c|c|c|c|c|}
\hline \multicolumn{10}{|c|}{ PIT NAME: TRJ0050.grid; UPPER SURFACE: Topo.grd; LOWER SURFACE: TRJ0050.grid } \\
\hline \multirow{3}{*}{ Seam } & \multicolumn{2}{|c|}{ Waste } & \multicolumn{2}{|c|}{ Oil shale } & \multirow{2}{*}{$\begin{array}{l}\text { Strip } \\
\text { ratio }\end{array}$} & \multicolumn{4}{|c|}{ Assay } \\
\hline & Volume & Tonnage & Volume & Tonnage & & ulj & $\operatorname{gg}$ & $\mathrm{pk}$ & $\mathrm{H} 2 \mathrm{O}$ \\
\hline & $\mathrm{m}^{3}$ & $\mathrm{t}$ & $\mathrm{m}^{3}$ & $\mathrm{t}$ & $\mathrm{m}^{3} / \mathrm{t}$ & $\%$ & $\%$ & $\%$ & $\%$ \\
\hline S1a & 14675 & 22013 & 295566 & 614187 & 0,02 & 12,12 & 5,28 & 75,88 & 6,69 \\
\hline S1b & 0 & 0 & 0 & 0 & 0,00 & 0,00 & 0,00 & 0,00 & 0,00 \\
\hline S2 & 0 & 0 & 0 & 0 & 0,00 & 0,00 & 0,00 & 0,00 & 0,00 \\
\hline TOTAL & 14675 & 22013 & 295566 & 614187 & 0,02 & 12,12 & 5,28 & 75,88 & 6,69 \\
\hline
\end{tabular}

Table 3. Quantities and quality for open pit mine 2 with discount factor of 0,6

\begin{tabular}{|c|c|c|c|c|c|c|c|c|c|}
\hline \multicolumn{10}{|c|}{ PIT NAME: TRJ0060.grid; UPPER SURFACE: Topo.grd; LOWER SURFACE: TRJ0060.grid } \\
\hline \multirow{3}{*}{ Seam } & \multicolumn{2}{|c|}{ Waste } & \multicolumn{2}{|c|}{ Oil shale } & \multirow{2}{*}{$\begin{array}{l}\text { Strip } \\
\text { ratio }\end{array}$} & \multicolumn{4}{|c|}{ Assay } \\
\hline & Volume & Tonnage & Volume & Tonnage & & ulj & $\operatorname{gg}$ & $\mathrm{pk}$ & $\mathrm{H} 2 \mathrm{O}$ \\
\hline & $\mathrm{m}^{3}$ & $\mathrm{t}$ & $\mathrm{m}^{3}$ & $\mathrm{t}$ & $\mathrm{m}^{3} / \mathrm{t}$ & $\%$ & $\%$ & $\%$ & $\%$ \\
\hline S1a & 7601784 & 11402676 & 9666036 & 20086022 & 0,38 & 12,11 & 5,10 & 77,03 & 5,76 \\
\hline S1b & 104577 & 156866 & 269151 & 559296 & 0,19 & 7,03 & 3,35 & 83,08 & 6,56 \\
\hline S2 & 0 & 0 & 0 & 0 & 0,00 & 0,00 & 0,00 & 0,00 & 0,00 \\
\hline TOTAL & 7706361 & 11559542 & 9935187 & 20645318 & 0,37 & 11,97 & 5,06 & 77,19 & 5,78 \\
\hline
\end{tabular}


Table 4. Quantities and quality for open pit mine 3 with discount factor of 0,7

\begin{tabular}{|c|c|c|c|c|c|c|c|c|c|}
\hline \multicolumn{10}{|c|}{ PIT NAME: TRJ0070.grid; UPPER SURFACE: Topo.grd; LOWER SURFACE: TRJ0070.grid } \\
\hline \multirow{3}{*}{ Seam } & \multicolumn{2}{|c|}{ Waste } & \multicolumn{2}{|c|}{ Oil shale } & \multirow{2}{*}{$\begin{array}{l}\text { Strip } \\
\text { ratio }\end{array}$} & \multicolumn{4}{|c|}{ Assay } \\
\hline & Volume & Tonnage & Volume & Tonnage & & ulj & gg & $\mathrm{pk}$ & $\mathrm{H} 2 \mathrm{O}$ \\
\hline & $\mathrm{m}^{3}$ & $\mathrm{t}$ & $\mathrm{m}^{3}$ & $\mathrm{t}$ & $\mathrm{m}^{3} / \mathrm{t}$ & $\%$ & $\%$ & $\%$ & $\%$ \\
\hline S1a & 14030684 & 21046026 & 14181280 & 29468699 & 0,48 & 111,87 & ב5,03 & 77,39 & 5,72 \\
\hline S1b & 228677 & 343016 & 1039801 & 2160707 & 0,11 & 7,46 & 3,64 & 82,11 & 6,80 \\
\hline $\mathrm{S} 2$ & 19307 & 28961 & 0 & 0 & 0,00 & 0,00 & 0,00 & 0,00 & 0,00 \\
\hline $\begin{array}{l}\text { TOTAL } \\
\end{array}$ & ב14278668 & 21418002 & (215221081 & 3031629406 & 0,45 & 111,57 & 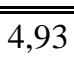 & $\overline{777,71}$ & $\overline{5,79}$ \\
\hline
\end{tabular}

Table 5. Quantities and quality for open pit mine 4 with discount factor of 0,8

\begin{tabular}{|c|c|c|c|c|c|c|c|c|c|}
\hline \multicolumn{10}{|c|}{ PIT NAME: TRJ0080.grid; UPPER SURFACE: Topo.grd; LOWER SURFACE: TRJ0080.grid } \\
\hline \multirow{3}{*}{ Seam } & \multicolumn{2}{|c|}{ Waste } & \multicolumn{2}{|c|}{ Oil shale } & \multirow{2}{*}{$\begin{array}{l}\text { Strip } \\
\text { ratio }\end{array}$} & \multicolumn{4}{|c|}{ Assay } \\
\hline & Volume & Tonnage & Volume & Tonnage & & ulj & gg & pk & $\mathrm{H} 2 \mathrm{O}$ \\
\hline & $\mathrm{m}^{3}$ & $\mathrm{t}$ & $\mathrm{m}^{3}$ & $\mathrm{t}$ & $\mathrm{m}^{3} / \mathrm{t}$ & $\%$ & $\%$ & $\%$ & $\%$ \\
\hline S1a & 23059402 & 34589103 & 18062744 & 37534383 & 0,61 & 11,85 & 5,00 & 77,49 & 5,67 \\
\hline S1b & 543918 & 815877 & 4908800 & 10200486 & 0,05 & 7,35 & 3,51 & 82,51 & 6,64 \\
\hline S2 & 1228803 & 1843205 & 73795 & 153346 & 8,01 & 16,42 & 8,13 & 69,72 & 5,72 \\
\hline TOTAL & 24832123 & 37248185 & 23045339 & 47888215 & 0,52 & 10,91 & 4,70 & 78,53 & 5,88 \\
\hline
\end{tabular}

Table 6. Quantities and quality for open pit mine 5 with discount factor of 0,9

\begin{tabular}{|c|c|c|c|c|c|c|c|c|c|}
\hline \multicolumn{10}{|c|}{ PIT NAME: TRJ0090.grid; UPPER SURFACE: Topo.grd; LOWER SURFACE: TRJ0090.grid } \\
\hline \multirow{3}{*}{ Seam } & \multicolumn{2}{|c|}{ Waste } & \multicolumn{2}{|c|}{ Oil shale } & \multirow{2}{*}{$\begin{array}{l}\text { Strip } \\
\text { ratio }\end{array}$} & \multicolumn{4}{|c|}{ Assay } \\
\hline & Volume & Tonnage & Volume & Tonnage & & ulj & $\operatorname{gg}$ & $\mathrm{pk}$ & $\mathrm{H} 2 \mathrm{O}$ \\
\hline & $\mathrm{m}^{3}$ & $\mathrm{t}$ & $\mathrm{m}^{3}$ & $\mathrm{t}$ & $\mathrm{m}^{3} / \mathrm{t}$ & $\%$ & $\%$ & $\%$ & $\%$ \\
\hline S1a & 34505887 & 51758831 & 20688573 & 42990855 & 0,80 & 11,97 & 5,05 & 77,30 & 5,74 \\
\hline S1b & 726930 & 1090395 & 7226016 & 15015661 & 0,05 & 7,31 & 3,49 & 82,58 & 6,63 \\
\hline $\mathrm{S} 2$ & 7234006 & 10851009 & 1840925 & 3825443 & 1,89 & 12,99 & 7,02 & 74,99 & 5,00 \\
\hline TOTAL & 42466823 & 63700235 & 29755514 & 61831959 & 0,69 & 10,90 & 4,79 & 78,44 & 5,91 \\
\hline
\end{tabular}

Table 7. Quantities and quality for open pit mine 6 with discount factor of 1,0

\begin{tabular}{|c|c|c|c|c|c|c|c|c|c|}
\hline \multicolumn{10}{|c|}{ PIT NAME: TRJ0100.grid; UPPER SURFACE: Topo.grd; LOWER SURFACE: TRJ0100.grid } \\
\hline \multirow{3}{*}{ Seam } & \multicolumn{2}{|c|}{ Waste } & \multicolumn{2}{|c|}{ Oil shale } & \multirow{2}{*}{$\begin{array}{l}\text { Strip } \\
\text { ratio }\end{array}$} & \multicolumn{4}{|c|}{ Assay } \\
\hline & Volume & Tonnage & Volume & Tonnage & & ulj & gg & pk & $\mathrm{H} 2 \mathrm{O}$ \\
\hline & $\mathrm{m}^{3}$ & $\mathrm{t}$ & $\mathrm{m}^{3}$ & $\mathrm{t}$ & $\mathrm{m}^{3} / \mathrm{t}$ & $\%$ & $\%$ & $\%$ & $\%$ \\
\hline S1a & 46550765 & 69826148 & 23031712 & 47859898 & 0,97 & 12,00 & 5,05 & 77,29 & 5,71 \\
\hline S1b & 935102 & 1402653 & 8375012 & 17403275 & 0,05 & 7,32 & 3,48 & 82,59 & 6,62 \\
\hline S2 & 9104509 & 13656764 & 2970218 & 6172114 & 1,48 & 12,78 & 6,88 & 75,23 & 5,10 \\
\hline TOTAL & 56590376 & 84885564 & 34376943 & 71435287 & 0,79 & 10,93 & 4,82 & 78,40 & 5,88 \\
\hline
\end{tabular}

Table 8. Quantities and quality for open pit mine 7 with discount factor of 1,1

\begin{tabular}{|c|c|c|c|c|c|c|c|c|c|}
\hline \multicolumn{10}{|c|}{ PIT NAME: TRJ0110.grid; UPPER SURFACE: Topo.grd; LOWER SURFACE: TRJ0110.grid } \\
\hline \multirow{3}{*}{ Seam } & \multicolumn{2}{|c|}{ Waste } & \multicolumn{2}{|c|}{ Oil shale } & \multirow{2}{*}{$\begin{array}{l}\text { Strip } \\
\text { ratio }\end{array}$} & \multicolumn{4}{|c|}{ Assay } \\
\hline & Volume & Tonnage & Volume & Tonnage & & ulj & gg & $\mathrm{pk}$ & $\mathrm{H} 2 \mathrm{O}$ \\
\hline & $\mathrm{m}^{3}$ & $\mathrm{t}$ & $\mathrm{m}^{3}$ & $\mathrm{t}$ & $\mathrm{m}^{3} / \mathrm{t}$ & $\%$ & $\%$ & $\%$ & $\%$ \\
\hline S1a & 52142384 & 78213576 & 23936602 & 49740258 & 1,05 & 12,02 & 5,05 & 77,27 & 5,71 \\
\hline S1b & 1045077 & 1567616 & 8915357 & 18526111 & 0,06 & 7,36 & 3,48 & 82,55 & 6,60 \\
\hline $\mathrm{S} 2$ & 10083711 & 15125567 & 3871409 & 8044787 & 1,25 & 12,72 & 6,82 & 75,28 & 5,15 \\
\hline TOTAL & 63271172 & 94906758 & 36723367 & 76311156 & 0,83 & 10,97 & 4,86 & 78,34 & 5,87 \\
\hline
\end{tabular}


Table 9. Quantities and quality for open pit mine 8 with discount factor of 1,2

\begin{tabular}{|c|c|c|c|c|c|c|c|c|c|}
\hline \multicolumn{10}{|c|}{ ME: TRJ0120.grid; UPPER SURFACE: Topo.grd; LOWER SURFACE: TR. } \\
\hline \multirow{3}{*}{ Seam } & \multicolumn{2}{|c|}{ Waste } & \multicolumn{2}{|c|}{ Oil shale } & \multirow{2}{*}{$\begin{array}{l}\text { Strip } \\
\text { ratio }\end{array}$} & \multicolumn{4}{|c|}{ Assay } \\
\hline & Volume & Tonnage & Volume & Tonnage & & ulj & gg & $\mathrm{pk}$ & $\mathrm{H} 2 \mathrm{O}$ \\
\hline & $\mathrm{m}^{3}$ & $\mathrm{t}$ & $\mathrm{m}^{3}$ & 1 & $\mathrm{~m}^{3} / \mathrm{t}$ & $\%$ & $\%$ & $\%$ & $\%$ \\
\hline S1a & 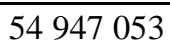 & 190 & 432532 & & 1,09 & 12,02 & $\overline{5,05}$ & 77,28 & $\overline{5,70}$ \\
\hline $\mathrm{S} 1 \mathrm{~b}$ & 1 & & & & 0,06 & 7,39 & 3,49 & 82,51 & 6,60 \\
\hline S2 & 10554901 & 15832352 & 4200550 & 8728743 & 1,21 & 12,74 & 6,83 & 75,27 & 5,14 \\
\hline TOTAL & 66586563 & 99879845 & 37751164 & 78446918 & 0,85 & 10,97 & 4,87 & 78,34 & 5,86 \\
\hline
\end{tabular}

Table 10. Quantities and quality for open pit mine 9 with discount factor of 1,3

\begin{tabular}{|c|c|c|c|c|c|c|c|c|c|}
\hline \multicolumn{10}{|c|}{ T NAME: TRJ0130.grid; UPPER SURFACE: Topo.grd; LOWER SURFACE: TRJ0130.grid } \\
\hline \multirow{3}{*}{ Seam } & \multicolumn{2}{|c|}{ Waste } & \multicolumn{2}{|c|}{ Oil shale } & \multirow{2}{*}{$\begin{array}{l}\text { Strip } \\
\text { ratio }\end{array}$} & \multicolumn{4}{|c|}{ Assay } \\
\hline & Volume & Tonnage & Volume & Tonnage & & ulj & $\operatorname{gg}$ & $\mathrm{pk}$ & $\mathrm{H} 2 \mathrm{O}$ \\
\hline & $\mathrm{m}^{3}$ & $\mathrm{t}$ & $\mathrm{m}^{3}$ & $\mathrm{t}$ & $\mathrm{m}^{3} / \mathrm{t}$ & $\%$ & $\%$ & $\%$ & $\%$ \\
\hline S1a & 173776 & 260 & 655576 & 512342 & 1,14 & 12,03 & 5,06 & 77,27 & 5,70 \\
\hline S1b & & & & 198 & 06 & 7,44 & 3,51 & 82, & 6,59 \\
\hline S2 & 10962963 & 16444445 & 4547052 & 9448774 & 1,16 & 12,73 & 6,81 & 75,29 & 5,14 \\
\hline TOTAL & 70261820 & 105392730 & 38749706 & 80521890 & 0,87 & 10,98 & 4,88 & 78,31 & 5,85 \\
\hline
\end{tabular}

Table 11. Quantities and quality for open pit mine 10 with discount factor of 1,4

\begin{tabular}{|c|c|c|c|c|c|c|c|c|c|}
\hline \multicolumn{10}{|c|}{ PIT NAME: TRJ0140.grid; UPPER SURFACE: Topo.grd; LOWER SURFACE: TRJ0140.grid } \\
\hline \multirow{3}{*}{ Seam } & \multicolumn{2}{|c|}{ Waste } & \multicolumn{2}{|c|}{ Oil shale } & \multirow{2}{*}{$\begin{array}{l}\text { Strip } \\
\text { ratio }\end{array}$} & \multicolumn{4}{|c|}{ Assay } \\
\hline & Volume & Tonnage & Volume & Tonnage & & ulj & gg & $\mathrm{pk}$ & $\mathrm{H} 2 \mathrm{O}$ \\
\hline & $\mathrm{m}^{3}$ & $\mathrm{t}$ & $\mathrm{m}^{3}$ & $\mathrm{t}$ & $\mathrm{m}^{3} / \mathrm{t}$ & $\%$ & $\%$ & $\%$ & $\%$ \\
\hline S1a & 69488143 & 104232215 & 25681690 & 53366552 & 1,30 & 12,06 & 5,06 & 77,24 & 5,69 \\
\hline S1b & 1143174 & 1714761 & 10075819 & 20937551 & 0,05 & 7,41 & 3,49 & 82,51 & 6,58 \\
\hline S2 & 11507914 & 17261871 & 5000209 & 10390435 & 1,11 & 12,72 & 6,82 & 75,33 & 5,10 \\
\hline TOTAL & 82139231 & 123208847 & 40757718 & 84694538 & 0,97 & 10,99 & 4,89 & 78,31 & 5,84 \\
\hline
\end{tabular}

Table 12. Quantities and quality for open pit mine 11 with discount factor of 1,5 PIT NAME: TRJ0150.grid; UPPER SURFACE: Topo.grd; LOWER SURFACE: TRJ0150.grid

\begin{tabular}{|c|c|c|c|c|c|c|c|c|c|}
\hline \multirow{3}{*}{ Seam } & \multicolumn{2}{|c|}{ Waste } & \multicolumn{2}{|c|}{ Oil shale } & \multirow{2}{*}{$\begin{array}{l}\text { Strip } \\
\text { ratio }\end{array}$} & \multicolumn{4}{|c|}{ Assay } \\
\hline & Volume & Tonnage & Volume & Tonnage & & ulj & gg & $\mathrm{pk}$ & $\mathrm{H} 2 \mathrm{O}$ \\
\hline & $\mathrm{m}^{3}$ & $\mathrm{t}$ & $\mathrm{m}^{3}$ & $\mathrm{t}$ & $\mathrm{m}^{3} / \mathrm{t}$ & $\%$ & $\%$ & $\%$ & $\%$ \\
\hline S1a & 74890758 & 112336137 & 26423161 & 54907329 & 1,36 & 12,06 & 5,06 & 77,26 & 5,68 \\
\hline S1b & 1212326 & 1818489 & 10216726 & 21230357 & 0,06 & 7,43 & 3,50 & 82,49 & 3,58 \\
\hline $\mathrm{S} 2$ & 11948171 & 17922257 & 5247721 & 10904765 & 1,10 & 12,69 & 6,80 & 75,37 & 5,10 \\
\hline TOTAL & 88051255 & 132076883 & 41887609 & 87042451 & 1,01 & 11,01 & 4,90 & 78,30 & 5,83 \\
\hline
\end{tabular}

Table 13. Review of the open pit mines values got by optimization

\begin{tabular}{|r|r|r|r|r|r|r|}
\hline Pit & \multicolumn{1}{|c|}{ Waste, $\mathrm{m} 3$} & \multicolumn{1}{c|}{ Oil shale, $\mathrm{t}$} & \multicolumn{1}{c|}{ ulj, $\%$} & \multicolumn{1}{c|}{ Costs, $\$$} & \multicolumn{1}{c|}{ Revenue, $\$$} & \multicolumn{1}{c|}{ Profit, $\$$} \\
\hline \hline 1 & 14675 & 614187 & 12,12 & 8979087 & 12534593 & 3555507 \\
\hline 2 & 7706361 & 20645318 & 11,97 & 337888916 & 416123976 & 78235060 \\
\hline 3 & 14278668 & 31629406 & 11,57 & 530019727 & 616213781 & 86194054 \\
\hline 4 & 24832123 & 47888215 & 10,91 & 818539733 & 879752302 & 61212570 \\
\hline 5 & 42466823 & 61831959 & 10,90 & 1108897521 & 1134871047 & 25973526 \\
\hline 6 & 56590376 & 71435287 & 10,93 & 1318763542 & 1314740278 & -4023264 \\
\hline 7 & 63271172 & 76311156 & 10,97 & 1422867622 & 1409618764 & -13248858 \\
\hline 8 & 66586563 & 78446918 & 10,97 & 1470413126 & 1449070534 & -21342592 \\
\hline 9 & 70261820 & 80521890 & 10,98 & 1518876505 & 1488755271 & -30121234 \\
\hline 10 & 82139231 & 84694538 & 10,99 & 1638766956 & 1567328778 & -71438178 \\
\hline 11 & 88051255 & 87042451 & 11,01 & 1702371815 & 1613709823 & -88661991 \\
\hline
\end{tabular}




\section{Conclusion}

Based on existing and new technical parameters, authors of mentioned technical solutions were determined optimal contour of newly-projected open pit mine that achieves the maximum possible profit and the estimated economic parameters.

Based on a result analysis of election the optimum contour of open pit mine for exploitation of oil shale from Aleksinac deposit, conclusion is that the optimum border for excavation is open pit mine No. 3, which gives maximum profit in relation to other projected contours. Quantities of waste and oil shale with its quality are shown in Table 4.

Optimal contour of the open pit mine for oil shale exploitation from Aleksinac deposits contains 31.629.406 tons of oil shale with $14.278 .668 \mathrm{~m}^{3}$ of waste.

Overburden coefficient for the optimal outline is $\mathrm{Kr}=0.45 \mathrm{~m}^{3} / \mathrm{t}$.

Bottom of the mine is on elevation of +25 $\mathrm{m}$. Maximum depth of the open pit mine is $200 \mathrm{~m}$.

An important factor in using Minex 5.2.3 is ability of changing and comparing several versions of input parameters of optimization. It is also important that less time is needed to determine the optimal contours, comparing with conventional projecting.

Projecting is much more improved by using this program, in terms of time and quality, due to the possibility of rapid analysis in order to select the best solution. The application of this and similar programs has become a necessity and standard in projecting of open pit mines.

This and other specialized computer programs for the mining industry provides great opportunities in design of open pit mines because, with them, it is possible to solve a series of complex problems in this area quickly and with high-quality.

\section{Gratitude}

\begin{abstract}
Implementers of research are gratitude to the Ministry of Science and Technological Development of Serbia, which is financially supported by research project TR-17005 under which they conducted the research.
\end{abstract}

\section{REFERENCES}

[1] STUDY ON OIL SHALE RESERVES FROM ALEKSINAC DEPOSIT, Coalproject Belgrade, 1984, Serbia (in Serbian)

[2] M. Ignjatović, R. Rajković, M. Maksimović, D. Ignjatović; DETERMINATION OF THE FINAL SLOPE ANGLES OF NAWLYPIT MINE DURING OIL SHALE EXPLOITATION FROM ALEKSINAC DEPOSIT BY PROGRAM GEOSTUDIO 2007 - Slope/W, Projekat MNTR br. TR-17005, T1/2009, 2008 2010, pages 5-11 (in Serbian)

[3] T. Milovanović, R. Trifunović: THE USE OF BITUMINOUS SHALE IN THE INDUSTRIAL PRODUCTION OF CEMENT CLINKER, CEMENT - no.1/86; Cement factory "Novi Popovac", Popovac, Serbia (in Serbian)

[4] M. Ignjatović, R. Rajković, D. Milanović, M. Maksimović, D. Urošević, D. Ignjatović, D. Mitić: Plenary lecture: OIL SHALES AS ENERGY RAW MATERIAL OF SERBIA FOR OBTAINING SYNTHETIC OIL, $3^{\text {rd }}$ International Symposium ENERGY MINING 2010, Tara 24-26.05.2010, pages 61-84, Serbia

[5] M. Ignjatović, S. Ignjatović, R. Pantović: EXPERIMENTAL DETERMINATION OF SHEAR STRENGTH ELEMENTS OF THE SAMPLES BY IN SITU MEASUREMENTS AND BY BARTON AND INCLINED PLANE METHOD, FOLLOWED BY RESULTS ANALYSES FOR “TAJMISTE" MINE, Technics Technologies Education Management 3/2010 Pages 514-520

[6] REPORT OF LABORATORY TESTING OF PHYSICAL - MECHANICAL AND DEFORMATION PROPERTIES OF OIL SHALE FROM THE SITE NEAR ALEKSINAC SUBOTINAC, Mining and Metallurgy Institute Bor, 2009, Pages 8-19, (in Serbian)

[7] M.Ignjatović, M.Ljubojev, D.Mitić, Z.Stojanović: OIL SHALE AS ENERGETIC POTENTIAL OF REPUBLIC SERBIA, Mines Engineering 1/2009, Bor, pages 23-32 (in Serbian)

[8] M. Ignjatović, R. Rajković, D. Milanović, D. Ignjatović, L. Đ. Ignjatović, M. Maksimović, V. Gardić; Plenary lecture: QUANTITIES OF OIL SHALE ASH FROM ALEKSINAC DEPOSIT, ITS DUMPING AND ENVIRONMENTAL PROTECTION, Faculty for 
Ecology and Environmental protection in Energetics, Mining and Supporting Industy, Divčibare 2010, Pages: 44-61, (in Serbian)

[9] M.Ignjatović, R.Rajković, M.Mikić, M.Ljubojev: POSSIBILITY OF OIL SHALE EXPLOITATION FOR OBTAINING THE SYNTHETIC OIL ON THE REPUBLIC SERBIA LOCATION; Second International Symposium Mining Energetic 08; Tara, Serbia, 15 -18. September 2008; Pages 135-140 (in Serbian)

[10] R. Rajković, D. Kržanović, R. Lekovski: STABILITY ANALYSIS OF INNER WASTE DUMP "KUTLOVACA" OF THE COAL OPEN PIT MINE "POTRLICA" - PLJEVLJA USING THE GEOSTUDIO 2007 SOFTWARE, Mines Engineering, 1/2010, Pages 75-80, Serbia

[11] M. Ignjatović, D. Milanović, S. Magdalinović, D. Urošević: COAL INDUSTRIAL PREPARATION AND CLEANING TECHNOLOGY - OIL SHALE - PROCESSING TECHNOLOGY AND SYNTHETIC OIL PRODUCTION, Monograph 2010, Pages 287-403, Serbia

[12] M. Ignjatovic, S. Ignjatovic, M. Negovanovic, R. Rajkovic, L. Đ. Ignjatovic, D. Ignjatovic: DETERMINATION OF THE FINAL SLOPE ANGLE OF THE OPEN PIT MINE DURING EXPLOITATION OF OIL SHALE FROM ALEKSINAC DEPOSIT BY GEOSTUDIO 2007 - SLOPE/W PROGRAM, Technics Technologies Education Management 3/2011

[13] V. Čokorilo, N. Lilić, J. Purga, V. Milisavljević: OIL SHALE POTENTIAL IN SERBIA, Oil shale Journal, 2009, Vol. 26, No. 4, pp. 451-462, Estonia 